\title{
Molecular Identification of Campylobacter Species from Positive Cultural Stool Samples of Diarrhoeic Children in Osun State
}

\author{
0. C. Adekunle1, A. A. Onilude', T. O. Sanusi ${ }^{3 *}$ \\ ${ }^{1}$ Department of Medical Microbiology and Parasitology, Ladoke Akintola University of Technology, Osogbo, Nigeria \\ ${ }^{2}$ Department of Microbiology, University of Ibadan, Ibadan, Nigeria \\ ${ }^{3}$ Department of Community Medicine, Ladoke Akintola University of Technology, Osogbo, Nigeria \\ Email: *toyintoro@yahoo.com
}

How to cite this paper: Adekunle, O.C., Onilude, A.A. and Sanusi, T.O. (2019) Molecular Identification of Campylobacter Species from Positive Cultural Stool Samples of Diarrhoeic Children in Osun State. Open Journal of Medical Microbiology, 9 , 8-15.

https://doi.org/10.4236/ojmm.2019.91002

Received: December 25, 2018

Accepted: February 10, 2019

Published: February 13, 2019

Copyright $\odot 2019$ by author(s) and Scientific Research Publishing Inc. This work is licensed under the Creative Commons Attribution International License (CC BY 4.0).

http://creativecommons.org/licenses/by/4.0/

\begin{abstract}
Death of infants from diarrhoea is a common occurrence in sub-Saharan Africa. This is attributed to unhygienic practices which aid the proliferation of diarrhoea-causing microorganisms. Among these microorganisms, Campylobacter species have been reported as one of the causal agents, Campylobacter spp. are human intestinal pathogens of global importance and their pathogenicity mechanisms are not well understood. This study was designed to investigate the molecular characterisation of Campylobacter gotten from cultural methods in Osun State. Campylobacters isolated were biochemically characterized and biotyped. Confirmation of Campylobacter was done using fla $A$ gene, hippuricase $\mathrm{O}$ for Campylobacter jejuni and aspartokinase gene for Campylobacter coli and single locus sequencing $\operatorname{gn} A$ gene were performed by PCR. Twenty five samples were amplified by PCR out of 57 Campylobacter strains that were positive for cultural methods from 815 stool samples with diarrhoea and 100 stool samples without diarrhoea. No Campylobacter was isolated from stools of children in the control group. Twenty-five isolates comprising of 18 Campylobater jejuni and $7 C$. coli were identified. The nucleotide sequence of the $\operatorname{gln} A$ for all the isolated Campylobacter spp. showed $91.0 \%$ similarity with the ones in the GenBank. The $C$. jejuni was classified into biotypes I (44.4\%) and II (55.6\%) and all $C$. coli were of biotype I.
\end{abstract}

\section{Keywords}

Campylobacters, Genes, Culture, Polymerase Chain Reaction (PCR), Identification 


\section{Introduction}

Campylobacter enteritis is a leading cause of acute bacterial gastrointestinal infection worldwide. The genus Campylobacter includes many species of which Campylobacter jejuni and Campylobacter coli are common pathogens and account for the majority of diagnosed human Campylobacter infections. Enteric infections caused by the two major species, C. jejuni $(85 \%-90 \%)$ and C. coli $(9 \%$ - 14\%) have increased considerably in recent years [1].

Contamination is mainly transmitted with food, such as raw milk, salad, vegetables, insufficiently cooked meat (poultry, lamb and pork), in water (either drunk or in contact) and by the environment [2]. The disease is characterized by a generally moderate fever, abdominal pain and diarrhoea, sometimes with blood in the faeces [3]. Campylobacter are fastidious organisms and require a micro-aerobic environment for growth. The organism produces diffuse, bloody, oedematous and exudative enteritis. Campylobacter causes tissue injury in the jejunum, ileum and the colon [4]. In a small number of cases, the infection may be associated with haemolytic ureamic syndrome and thrombotic thrombocytopaenic purpura through a poorly understood mechanism [5]. Molecular methods based on PCR amplification are more accurate than bacterial culture [6] [7]. Therefore, this study identified Campylobacter using cultural and molecular methods.

\section{Materials and Methods}

\subsection{Sampling and Sample Collection Sites}

This study was carried out prospectively at the General Hospitals and Private Hospitals in Osun state between January 2018 and October 2018. Osogbo is in the Southwestern part of Nigeria. Subjects were patients between the age of 1 and 36 months, who presented with watery, offensive diarrhea with or without mucus, with or without blood and fever at-the paediatric units of these hospitals. It is a non-invasive study. However, informed consent was obtained from each of the mothers of all the children. The study was approved by the Ethical and Research Committee of the Ladoke Akintola University of Technology, Ogbomoso Oyo state, Nigeria. A total of 915 subjects were examined during the period of study, 815 (89\%) with diarrhea and 100 (11\%) without diarrhea which served as control group.

\subsection{Growth and Incubation Methods}

Collected rectal swabs were used to inoculate Butzler-type-medium (a selective medium which consisted of Butzler agar, 5\% sheep blood and CAT from Oxoid comprised of cefoperazone, amphotericin B and teichoplanin as selective agents). The plates were incubated in an anaerobic incubator. The incubation was done in an atmosphere with reduced oxygen (5\%) but with added carbon-dioxide (10\%). They were incubated at $42^{\circ} \mathrm{C}$ which prohibits growth of most of the other bacteria present in faeces, thus simplifying the identification of Campylobacter. 
Incubation was continued for 72 hours. Growing colonies were obtained and subcultured to obtain pure ones. Biochemical tests performed include catalase, oxidase and hydrogen sulphide production. The isolates were resistant to cephalothin, and did not grow aerobically. Biotyping was done by rapid hippurate hydrolysis Test, rapid $\mathrm{H}_{2} \mathrm{~S}$ test and Deoxyribonucleic acid (DNA) hydrolysis.

Rapid Hippurate Hydrolysis Test using 1\% Sodium hippurate in $\mathrm{H}_{2} \mathrm{O}$ and $3.5 \%$ Ninhydrin in butanol-acetone (1:1). A loopful $(2 \mathrm{~mm})$ of a $24-48$ hours old culture emulsified in $0.4 \mathrm{ml}$ of sodium hippurate solution in a test-tube. The test-tube was incubated for 2 hours in a $37^{\circ} \mathrm{C}$ water bath. After, it was slowly overlaid with $0.2 \mathrm{ml}$ of Ninhydrin reagent. Incubation was continued for 10 minutes. Crystal violet-like colour was read as positive reaction.

Rapid $\mathrm{H}_{2} \mathrm{~S}$ Test: A large (about $0.5 \mathrm{~cm}$ in diameter) ball-like inoculum of the culture was inoculated into mixture of $0.05 \%$ each of ferrous sulphate, sodium metabisulphite and sodium pyruvate (FBP) broth (Oxoid). The test-tubes were incubated in a $37^{\circ} \mathrm{C}$ water bath for 2 hours. Blackening around the bacterial mass indicates positive reaction.

Deoxyribonucleic acid (DNA) hydrolysis was carried using DNA Test agar and $0.5 \%$ methyl green solution. The DNA containing medium (DNase test agar) was prepared according to be manufacturer's instruction (Qiagen Ltd). Methyl green was added to $100 \mathrm{ml}$ of DNase agar, autoclaved and dispensed into $25 \mathrm{ml}$ plate. All the strains of Campylobacters were tested for DNA hydrolysis. A loopful of 48 hours growth culture from the blood agar plate was used to inoculate a circular area approximately $1.0 \mathrm{~cm}$ in diameter on the surface of DNase test agar plate and incubated at $37^{\circ} \mathrm{C}$ in an anearobic jar. All plates were examined daily for 5 consecutive days during incubation. An area of growth surrounded by a clear or colourless zone in the green agar was a positive test of DNA hydrolysis.

\subsection{Extraction of DNA from the Sample}

A total of $100 \mathrm{ml}$ of each Campylobacter isolates was added to isotonic buffer and $750 \mu \mathrm{l}$ lysis solution. Later centrifuged at 10,000 $\mathrm{xg}$ for 1 minutes. Binding buffer was added, later pre wash buffer and DNA wash buffer. A volume of 100 $\mu$ DNA Elution Buffer was added, centrifuged at 10,000 $\mathrm{xg}$ for 30 seconds and DNA was eluted.

\subsection{PCR Amplification for flaA Gene}

One of the best characterized Campylobacter virulence markers is the fla $A$ gene which determines the major component of the flagella, hence bacteria motility and enterocyte colonization [8]. They also participate in adhesion and colonization [9]. All isolates were further identified by a molecular method based on $16 \mathrm{~S}$ rRNA species specific gene amplification by PCR and subsequent sequence analysis of the PCR products. PCR amplification was done using primers: flaAF GGATTTCGTATTAACACAAATGGTGC flaA $48^{\circ} \mathrm{C}$ flaAR

CTGTAGTAATCTTAAACATTTTG [10]. The PCR was performed in a $25 \mu \mathrm{l}$ 
volume, the PCR mixture contained $2.5 \mathrm{~m} \mathrm{MgCl}_{2}$, primers $0.5 \mu \mathrm{l}$, Taq polymerase 1.25 U, PCR buffer $0.5 \mu \mathrm{l}$ and sterile water $15.9 \mu \mathrm{l}$. Amplification was carried out in an eppendorf master cycler. The cycling parameter consisted of an initial denaturation of $94^{\circ} \mathrm{C}$ for two minutes, followed by 35 consecutive cycles of $94^{\circ} \mathrm{C}$ for one minute, annealing at $50^{\circ} \mathrm{C}$ for one minute and final extension at $72^{\circ} \mathrm{C}$ for one minute.

\subsection{PCR Amplification Species-Specific for $C$. jejuni, and for C. coli}

PCR was performed in $25 \mu \mathrm{l}$ volumes, the PCR mixture contained $1 \mu \mathrm{l}$ of template DNA, $10 \mathrm{mM}$ Tris- $\mathrm{HCl}, 50 \mathrm{mM} \mathrm{KCl}, 2.5 \mathrm{mM} \mathrm{MgCl}_{2}, 200 \mu \mathrm{M}$ dATP, dCTP, dGTP, dTTP, $1.25 \mathrm{U}$ Taq purple DNA polymerase (Fermentas), $1 \mu \mathrm{M}$ of each oligonucleotide. The PCR was performed on a PTC-200 thermocycler, with the following programme: initial denaturation $5 \min 95^{\circ} \mathrm{C}, 2 \times\left(1 \min 94^{\circ} \mathrm{C}, 1 \mathrm{~min}\right.$ $\left.72^{\circ} \mathrm{C}\right), 2 \times\left(1 \min 60^{\circ} \mathrm{C}, 1 \min 72^{\circ} \mathrm{C}\right), 2 \times\left(1 \min 94^{\circ} \mathrm{C}, 1 \min 58^{\circ} \mathrm{C}, 1 \min 72^{\circ} \mathrm{C}\right)$,

$\begin{array}{llll}\text { Primer } & & \text { Product bp } & \text { Annealing } \\ \text { C. jejuni } & \text { Hip O F-GAA GAG GGT TTG GGT GGT } & 344 & 56.2^{\circ} \mathrm{C} \\ & \text { R-AGC TAG CTT CGC ATA ATA ACT TG } & & \\ & \begin{array}{l}\text { C. coli } \text { Asp-primer AAAGCTGCAGCTATGGC } \\ \text { AAG CGCAATATCAGCCACTC }\end{array} & 500 & 50^{\circ} \mathrm{C} \\ & \text { AA CATCATC }\end{array}$

The PCR products were visualized by electrophoresis in $1.5 \%$ agarose gel, stained with ethidium bromide $(1 \mu \mathrm{g} / \mathrm{ml})$ and viewed under UV light.

The SLST method was developed by Scholz and Jensen [11] to characterize the Campylobacter strains and to identify clonal lineages in this species. This method uses genetic variation at multiple chromosomal locations and allows generation of sequence data, which are deposited in internet databases for comparison with DNA sequences of other isolates. This was done using an ABI (applied Biosystem) 33,100 Genetic analyser (Life Technologies) a multicolour fluorescence based DNA analysis system with 16 capillaries operating in parallel.

\subsection{Single-Locus Sequencing Typing Method}

DNA amplification of gene was done using the primer described by Jonas Waldensrom.

gInA Glutamine synthetase gene was amplified

F-TAGGAACTTGGCATCATATTACC

R-TTGGACGAGCTTCTTCTACTGGC

\section{Results}

Cultural method gave a total of 57 Campylobacter isolates while only 25 of those 57 isolates were amplified by PCR as shown in Table 1. The result of PCR assays were not in complete agreement with phenotypic methods for identification of the bacterial isolates. From the 815 subjects with diarrhea, 347 (42.6\%) were females, 468 (57.4\%) were males, 25 were positive for Campylobacter species giv- 
ing a prevalence of $3.06 \%$. Eighteen $C$. jejuni were amplified by PCR and 7 were C. coli. as shown in Figure $1 \&$ Figure 2. Fifteen were males while ten were females. $C$.jejuni biotype I were 8 while biotype II were 10 and all the $C$. coli belong to biotype I as shown in Table 2. All $C$. jejuni belong to subspp jejuni.

Table 1. Distribution of Isolates among Children with Diarrhea.

\begin{tabular}{cccc}
\hline Sex & Number Examined & PCR Campylobacter & Cultural Campylobacter \\
\hline Male & 468 & 15 & 36 \\
Female & 397 & 10 & 21 \\
Total & 815 & 25 & 57 \\
\hline
\end{tabular}

Table 2. Distribution of Biotypes of Campylobacter Species.

\begin{tabular}{ccc}
\hline Campylobacter species & Different biotype & Number positive \\
\hline Campylobacter jejuni & Biotype I & 8 \\
& Biotype II & 10 \\
Campylobacter coli & Biotype I & 7 \\
\hline
\end{tabular}

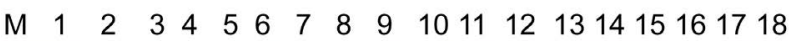

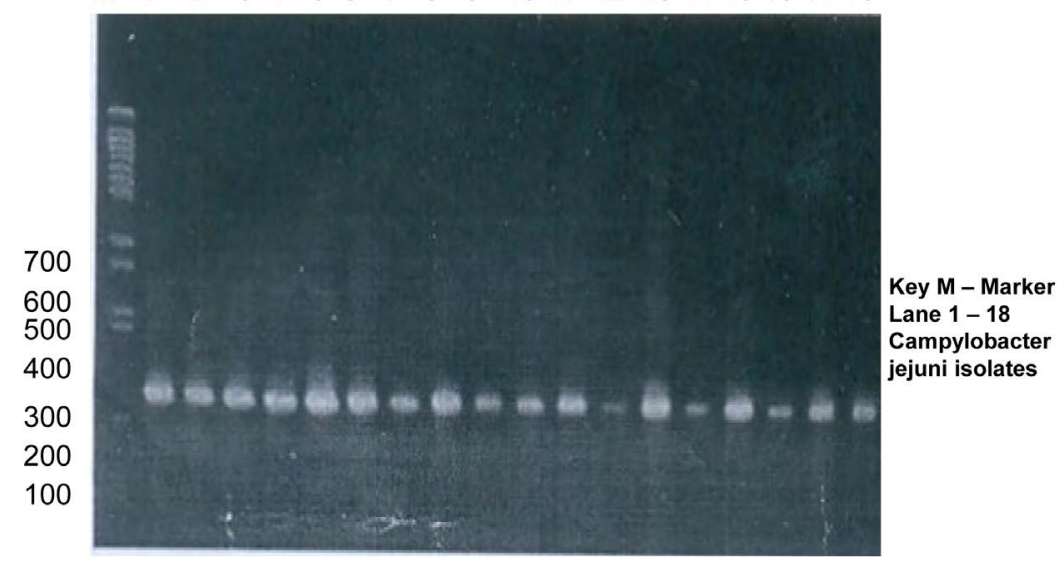

Figure 1. Agarose gel electrophoretogram of Campylobacter jejuni after PCR result.

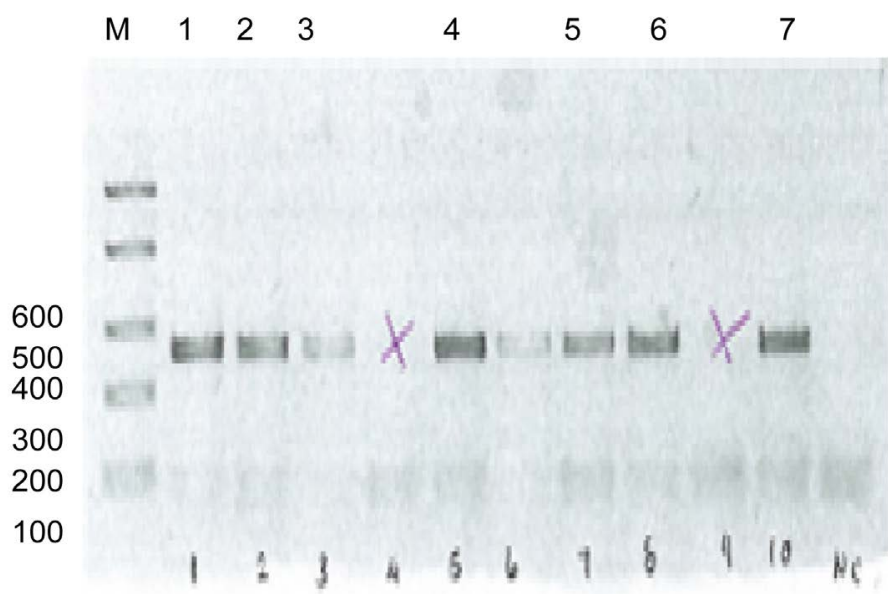

Figure 2. Agarose gel electrophoretogram of Campylobacter coli after PCR results. 


\section{Result of Sequencing}

glnA Glutamine synthetase PCR confirm it to be Campylobacter jejuni. All Campylobacter belong to ST-21 and ST-50. Thirteen Campylobacter jejuni belong to ST-21 and 5 Campylobacter jejuni belong to ST-50.

\section{Discussion}

Molecular methods were also used for the detection of Campylobacters. One of the best characterized Campylobacter pathogenic markers is the fla $A$ gene which determines flagella formation, hence bacterial motility and enterocyte colonization [12] [13]. Results showed that all $C$. jejuni and C. coli confirmed by PCR possessed fla $A$ gene. The adoption of molecular techniques in microbial diagnostic has become a promising alternative approach, as they possess inherent advantages such as shorter time to results, excellent detection limits, specificity and potential for automation. In the study, 57 isolates were gotten when cultural method was adopted; these isolates were later identified by molecular method only 25 were confirmed to be Campylobacter. Since molecular method is more confirmatory when compared with cultural method, the implication is that there could be false positive results when cultural method was used. Organisms such as Campylobacter, Helicobacter and Arcobacter belong to same class i.e. Epsilon Proteobacteria and have certain characteristics which are similar. These similar characteristics may give false-positive results. However, they can be distinguished using DNA base composition using PCR technique. Campylobacter spp. have different guanine plus cytosine $(\mathrm{G}+\mathrm{C})$ content from other members such as Wolinella and Helicobacter [14].

Persson and Olsen (2005) observed $10^{3}$ fold higher sensitivity of culturing compared to direct DNA purification is expected to be less pronounced on routine diagnostic samples, and the direct DNA purification should be considered advantageous with respect to the analysis of samples containing dead and noncultivable bacteria that may constitute a significant proportion of the bacteria in a given stool sample [15]. No attempt was made during this study to identify Campylobacters directly in faecal samples or to determine the minimum numbers of bacteria required to produce a positive result.

However, there is evidence that PCR-based assays can be successfully applied to the direct detection of Campylobacter spp. and other pathogenic bacteria in clinical stool samples [16].

The result obtained from study showed that $C$. jejuni had the highest prevalence of $72 \%$ (18 of 25) and C. coli with $28 \%$. This fact conforms with the study by de Wit et al. that $C$. jejuni and $C$. coli are the two main species isolated in developing countries. The isolation rate of $C$. jejuni exceeds that of $C$. coli, similar to observations in most developed countries [17]. The most frequently isolated Campylobacter species was $C$. jejuni which is in conformity with other reports in Lagos and Ile-Ife. The result obtained from study showed that $C$. jejuni had the highest prevalence. 


\section{Conflicts of Interest}

The authors declare no conflicts of interest regarding the publication of this paper.

\section{References}

[1] Wang, X., Wang, J., Sun, H., Xia, S., Duan, R. and Liang, J. (2015) Etiology of Childhood Infectious Diarrhea in a Developed Region of China: Compared to Childhood Diarrhea in a Developing Region and Adult Diarrhea in a Developed Region. PLOS ONE, 10, e0142136. https://doi.org/10.1371/journal.pone.0142136

[2] Silva, J., Leite, D., Fernandes, M., Mena, C., Gibbs, P.A. and Teixeira, P. (2011) Campylobacter spp. as a Foodborne Pathogen: A Review. Frontiers in Microbiology, 2, 200. https://doi.org/10.3389/fmicb.2011.00200

[3] Szczepanska, B., Andrzejewska, M., Spica, D. and Klawe, J.J. (2017) Prevalence and Antimicrobial Resistance of Campylobacter jejuni and Campylobacter coli Isolated from Children and Environmental Sources in Urban and Suburban Areas. BMC Microbiology, 17, 80.

[4] Whyte, P., McGill, K., Cowley, D., Madden, R.H., Moran, L., Scates, P., Carroll, C., O'Leary, A., Fanning, S., Collins, J.D., McNamara, E., Moore, J.E. and Cormican, M. (2004) Occurrence of Campylobacter in Retail Foods in Ireland. International Journal Food Microbiology, 95, 111-118. https://doi.org/10.1016/j.ijfoodmicro.2003.10.018

[5] Nyati, K.K. and Nyati, R. (2013) Role of Campylobacter jejuni Infection in the Pathogenesis of Guillain-Barré Syndrome: An Update. BioMed Research International.

[6] Aly, B.H., Hamad, M.S., Mohey, M. and Amen, S. (2012) Polymerase Chain Reaction (PCR) versus Bacterial Culture in Detection of Organisms in Otitis Media with Effusion (OME) in Children. International Journal of Molecular Sciences, 13, 2535-2550.

[7] Rhoads, D.D., Wolcott, R.D., Sun, Y. and Dowd, S.E. (2017) Comparison of Culture and Molecular Identification of Bacteria in Chronic Wounds. Methods in Molecular Biology, 1535, 97-107.

[8] Nuijten, P.J., van den Berg, A.J., Formentini, I., van der Zeijst, B.A. and Jacobs, A.A. (2000) DNA Rearrangements in the Flagellin Locus of an flaA Mutant of Campylobacter jejuni during Colonization of Chicken Ceca. Infectious Immunology, 68, 7137-7140. https://doi.org/10.1128/IAI.68.12.7137-7140.2000

[9] Wassenaar, T.M., Van Der Zeijst, B.A.M., Ayling, R. and Newell, D.G. (1993) Colonization of Chicks by Motility Mutants of Campylobacter jejuni Demonstrates the Importance of Flagellin A Expression. Journal of General Microbiology, 139, 1171-1175. https://doi.org/10.1099/00221287-139-6-1171

[10] Datta, S., Niwa, H. and Itoh, K. (2003) Prevalence of 11 Pathogenic Genes of Campylobacter jejuni by PCR in Strains Isolated from Humans, Poultry Meat and Broiler and Bovine Faeces. Journal of Medical Microbiology, 52, 345-348. https://doi.org/10.1099/jmm.0.05056-0

[11] Scholz, C.F. and Jensen, A. (2017) Development of a Single Locus Sequence Typing (SLST) Scheme for Typing Bacterial Species Directly from Complex Communities. Methods in Molecular Biology, 1535, 97-107. https://doi.org/10.1007/978-1-4939-6673-8_7

[12] Wieczorek, K. and Osek, J. (2011) Molecular Characterization of Campylobacter 
spp. Isolated from Poultry Faeces and Carcasses in Poland. Acta Veterinaria Brno, 80, 19-27. https://doi.org/10.2754/avb201180010019

[13] El-Jakee, J., Ata, N.S., Hakim, A.S., Syame, S.M. and Omara, S.T. (2015) Prevalence of Virulence Genes and Antimicrobial Resistance Patterns of Campylobacter Species Isolated from Chicken in Egypt. Asian Journal of Poultry Science, 9, 250-261.

[14] Takai, K. (2006) Sulfurimonas paralvinellae sp. nov., a Novel Mesophilic, Hydrogen- and Sulfur-Oxidizing Chemolithoautotroph within the Epsilonproteobacteria Isolated from a Deep-Sea Hydrothermal Vent Polychaete Nest, Reclassification of Thiomicrospira denitrificans as Sulfurimonas denitrificans comb. nov. and Emended Description of the Genus Sulfurimonas. International Journal of Systematic and Evolutionary Microbiology, 56, 1725-1733. https://doi.org/10.1099/ijs.0.64255-0

[15] Maher, M., Finnegan, C., Collins, E., Cyril, C. and Cormican, M. (2003) Evaluation of Culture Methods and a DNA Probe Based PCR Assay for Detection of Campylobacter Species in Clinical Specimens of Faeces. Journal of Clinical Microbiology, 41, 2980-2986. https://doi.org/10.1128/JCM.41.7.2980-2986.2003

[16] Bessède, E., Delcamp, A., Sifré, E., Buissonnière, A. and Mégraud, F. (2011) New Methods for Detection of Campylobacters in Stool Samples in Comparison to Culture. Journal of Clinical Microbiology, 49, 941-944. https://doi.org/10.1128/JCM.01489-10

[17] De Wit, M.A., Koopmans, M.P., Kortbeek, L.M., van Leeuwen, N.J., Vinje, J. and van Duynhoven, Y.T. (2001) Etiology of Gastroenteritis in Sentinel General Practices in the Netherlands. Clinical Infectious Diseases, 33, 280-288.

https://doi.org/10.1086/321875 